\title{
Epiphyte-phorophyte relationships: assessing the differences between Seasonal Semideciduous and Swamp Forests in Southeastern Brazil ${ }^{1}$
}

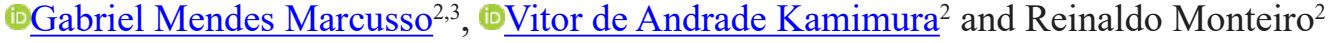 \\ Received: 12 March 2018; accepted: 23 April 2019 \\ How to cite: Marcusso, G.M., Kamimura, V.A. \& Monteiro, R. 2019. Epiphyte-phorophyte relationships: assessing the \\ differences between Seasonal Semideciduous and Swamp Forests in Southeastern Brazil. Hoehnea 46: e232018. http:// \\ dx.doi.org/10.1590/2236-8906-23/2018.
}

\begin{abstract}
Epiphyte-phorophyte relationships: assessing the differences between Seasonal Semideciduous and Swamp Forests in Southeastern Brazil). Vascular epiphytes are responsible for a considerable portion of tropical biodiversity; however, the variation of epiphytes-phorophytes relationships in different vegetation types are still poorly understood. In this study, we aimed to assess the presence, abundance, vertical distribution, and life cycle (holoepiphyte and hemiepiphyte) of vascular epiphytes in two vegetation types [Seasonal Semideciduous Forest (- SSF), and Swamp Forest (- SF)] in order to determine any correlation with phorophyte size (diameter and height) and the specificity of phorophyte species to the epiphytic colonization. There was a higher number of phorophytes in SF; however, epiphytes density did not differ between the vegetation types. The recorded vertical distribution also showed different patterns: in the SSF, most epiphytes were found in the canopy, while in the SF they occurred mainly on the trunks of the trees. The abundance of epiphytes was positively correlated with the phorophyte size in the two vegetation types. In the SSF, colonization of phorophytes by epiphytes appeared to be less species-specific than in the SF, where trees density is likely to be a more significant factor to epiphytic colonization. The results showed the importance of the forest heterogeneity in the conservation and maintenance of vascular epiphytes assemblage, demonstrated by differences in the abundance and distribution of the epiphytes, even in contiguous forests. Keywords: atlantic forest, hemiepiphytes, holoepiphytes, host tree, vertical distribution
\end{abstract}

RESUMO - (Relações epífita-forófito: avaliando as diferenças entre florestas estacional semidecidual e paludosa no Sudeste do Brasil). As epífitas vasculares são responsáveis por uma parcela considerável da biodiversidade tropical; no entanto, suas relações com os forófitos entre diferentes tipos de vegetação em que ocorrem ainda são pouco compreendidas. Neste trabalho, objetivamos avaliar a presença, a abundância, a distribuição vertical e a categoria ecológica (holoepífita e hemiepífita) das epífitas vasculares em dois tipos de vegetação [Floresta Estacional Semidecídua (- FES) e Floresta Paludosa (- FP)], com o intuito de investigar se há correlação com o tamanho dos forófitos (diâmetro e altura) e possíveis especificidades na colonização destes pelas epífitas. Na FP foi registrado um maior número de forófitos; no entanto, a abundância de epífitas não apresentou diferenças entre os dois tipos de vegetação. A distribuição vertical apresentou diferença entre os tipos de vegetação, com mais epífitas no fuste na FP, enquanto na FES a copa apresentou mais epífitas. Houve relação positiva da abundância de epífitas com o porte dos forófitos em ambas as fitofisionomias. Por outro lado, a densidade das espécies de árvores é provavelmente mais importante na FP para a colonização das epífitas. Os resultados mostraram a importância da heterogeneidade florestal na conservação e manutenção da assembleia de epífitos vasculares, demonstrada pelas diferenças na abundância e distribuição das epífitas, mesmo em florestas contíguas.

Palavras-chave: árvore hospedeira, distribuição vertical, floresta atlântica, hemiepífitas, holoepífitas

\section{Introduction}

Traditionally, vascular epiphytes are defined as plants that grow on other live plants (phorophytes), using them only as mechanical support, either without floor connection (holoepiphytes) or connected just in a part of the life cycle (hemiepiphytes) (Madison 1977). Recently, some conceptual changes have been made by Zotz $(2013,2016)$, that accepted only the holoepiphytes and the traditionally primary

1. Parte da Dissertação de Mestrado do primeiro Autor

2. Universidade Estadual Paulista, Instituto de Biologia, Departamento de Botânica, Av. 24A, 13506-000 Rio Claro, São Paulo, Brasil

3. Corresponding author: gabrielmarcusso@hotmail.com 
hemiepiphytes as epiphytes, excluding the secondary hemiepiphytes or nomadic vines (as per Zotz 2013), by the fact that they are unlikely to lose ground connection after climbing up. These changes regards different epiphyte-phorophyte relationships. Besides these intricate relationships with the trees, the diversity of this guild represent a significant portion of the tropical biodiversity (Gentry \& Dodson 1987, Kersten 2010, Zotz 2013), corresponding to $50 \%$ of the total flowering and non-flowering plant richness in some localities (Kersten 2010).

Many biotic factors influence the vascular epiphyte distribution patterns, as phorophyte size, bark types, toxins on bark, crown architecture, microhabitats provided by the phorophytes, bryophytes cover, dispersal syndromes of the epiphytes and forest types (ter Steege \& Cornelissen 1989, Wolf 1994, Hernández et al. 1999, Arévalo \& Betancur 2006, Wagner et al. 2015). In addition, abiotic factors, as luminosity and humidity, also influence the spatial distribution of the vascular epiphytes (Gentry \& Dodson 1987, ter Steege \& Cornelissen 1989, Wolf 1994, Hernández et al. 1999, Arévalo \& Betancur 2006, Breier 2005, Joanitti 2013).

The diversity of vascular epiphytes are known to vary at both local (ter Steege \& Cornelissen 1989, Arévalo \& Betancur 2004, 2006, Kersten et al. 2009, Joanitti 2013) and on a large scale (Gentry \& Dodson 1987, Nieder et al. 1999, Breier 2005, Leitman et al. 2015). Their distribution might follow ecological gradients, both horizontally - among different vegetation types and phorophytes (Benavides et al. 2011, Marcusso et al. 2016) - and vertically, exhibiting variations on the same phorophyte, from the floor to the canopy (ter Steege \& Cornelissen 1989, Nieder et al. 1999, Rogalski et al. 2016). These distribution changes occur mainly due to the humidity that increases from the canopy to the ground, and to the luminosity and wind that follow the opposite way (Benzing 1995).

In Brazil, there is an increasing number of studies on quantitative and spatial distribution of epiphytes (e.g. Bonnet \& Queiroz 2006, Kersten \& Waechter 2011, Basílio et al. 2015), but few investigate phorophytes colonization trends by epiphytes (e.g. Fontoura et al. 2009, Alves et al. 2008, Silva et al. 2010), and between vegetation types (e.g. Kersten et al. 2009, Joanniti 2013, Rogalski et al. 2016, Padilha et al. 2017). The Seasonal Semideciduous Forest (SSF) and Swamp Forest (SF) are two forest types of the Atlantic Forest Domain that can show contiguous occurrence and differences in some of the features responsible for vascular epiphytes diversity and distribution, such as humidity, especially because of the waterlogged soil in the SF (Ivanauskas et al. 1997, Marcusso \& Monteiro 2016).

In this context, Kersten et al. (2009) found higher epiphytes diversity and abundance in an alluvial forest than in a contiguous no alluvial forest in the Atlantic Forest domain. Moreover, Quaresma et al. (2017) observed that the nutritional aspects of the soil influences the epiphytes diversity in two seasonally floodplain forest types in the Amazon, where the most richness nutritional one, the Várzea forest, supported more epiphytes than the nutritional-poor Igapó forest. These results show the importance of understanding what patterns of diversity might occur in different forest types like SSF and SF.

Thus, the lack of adequate studies evaluating the colonization and the relationships between vascular epiphytes and phorophytes in these forest types, and how they influence the epiphytes led us to investigate the following questions: (1) Are there variations in the presence, abundance, vertical distribution and life cycle of vascular epiphytes in these two forest types? (2) Are there correlations between vascular epiphytes abundance and phorophytes size? (3) Do vascular epiphytes have affinities for certain host tree species?

\section{Material and methods}

Study area - The study was conducted in Botucatu city, São Paulo State, Southeastern Brazil (figure 1), at the Escola do Meio Ambiente (22\%55'23"S and $\left.48^{\circ} 27^{\prime} 28^{\prime \prime} \mathrm{W}\right)$. The site is located in Paraná Basaltic Plateau, a geomorphologic province that is characterized in three units: Peripheral Depression, Botucatu Cuestas and Western Plateau (Ponçano et al. 1981). The soils are formed from Bauru and Serra Geral group, and the main types are the latosol, neosol and patches of hydromorphic soils (e.g. organosol and argisol) (Campos et al. 2004). According to Köeppen's classification, its climate is subtropical humid with dry winter and hot summer ( $\mathrm{Cwa})$. The average annual temperature is $20.7^{\circ} \mathrm{C}$, with a long-term mean precipitation of $1358 \mathrm{~mm}$, the rainiest months from October to March (average of $169 \mathrm{~mm}$ ), and the driest from April to September (average of $57.5 \mathrm{~mm}$ ) (CEPAGRI 2018).

The site is located at an elevation of 850 meters with patches of Seasonal Semideciduous Forest (sensu IBGE 2012), Swamp Forest (sensu Rodrigues 2000) 
and anthropic areas. The SSF covers 14 hectares, and it is characterized by about $30 \%-50 \%$ of the individual trees sheding leaves simultaneously during the driest season (IBGE 2012). In the studied area, the upper stratum of SSF is generally formed by emergent trees of 15-20 m tall, and average canopy of $13 \mathrm{~m}$. The main tree species in the canopy are Ocotea velutina (Mart. ex Nees) Rohwer (Lauraceae), Croton floribundus Spreng. (Euphorbiaceae), Copaifera langsdorfii Desf. (Fabaceae), Machaerium villosum Vogel (Fabaceae), Aniba firmula (Nees \& Mart.) Mez (Lauraceae) and Cordia sellowiana Cham. (Boraginaceae). In the understory, the most common species are Cordiera sessilis (Vell.) Kuntze (Rubiaceae), Metrodorea nigra A. St.-Hil. (Rutaceae), Actinostemon concepcionis (Chodat \& Hassl.) Hochr. (Euphorbiaceae), Esenbeckia grandiflora Mart. (Rutaceae), Casearia sylvestris Sw. (Salicaceae), Maytenus gonoclada Mart. (Celastraceae), Mollinedia elegans Tul. (Monimiaceae) and Hirtella hebeclada Moric. ex DC. (Chrysobalanaceae). Epiphytic plants have low richness (Marcusso \& Monteiro 2016), while climber plants are conspicuous in this forest.

$\mathrm{SF}$ is found in areas where groundwater is close to the soil surface (Ivanauskas et al. 1997, Rodrigues 2000). In the studied area, it covers approximately two hectares, with emergent trees reaching about 15-18 m height, with canopy averaging $10 \mathrm{~m}$. The main tree species in the canopy are Protium heptaphyllum (Aubl.) Marchand (Burseraceae), Magnolia ovata (A.St.-Hil.) Spreng. (Magnoliaceae), Tapirira guianensis Aubl. (Anacardiaceae), Handroanthus umbellatus (Sond.) Mattos (Bignoniaceae), Pera glabrata (Schott) Poepp. ex Baill. (Peraceae) and Callophyllum brasiliense Cambess. (Callophylaceae). In the understory, the main species are Myrsine gardneriana A. DC. (Primulaceae), Hedyosmun brasiliense Mart. (Chloranthaceae) and Dendropanax cuneatus (DC.) Decne. \& Planch. (Araliaceae). More species of vascular epiphytes occur in this type of forest (Marcusso \& Monteiro 2016), but fewer climbers were observed.

Sampling - Fieldwork was carried out from June 2013 to June 2014. Trees were used as sample units in this study. We set seven linear transects, about 10 meters from each other, three in the SF (with a total length of $290 \mathrm{~m}, 240 \mathrm{~m}$ and $260 \mathrm{~m}$ ) and four in the SSF (230 m, $210 \mathrm{~m}, 150 \mathrm{~m}$ and $200 \mathrm{~m}$ long). In the $\mathrm{SF}$, only three transects were set because of the forest fragment size and shape. Nevertheless, the number of trees sampled was the same in both vegetation types. We used the point-centered quarter method (Cottam $\&$ Curtis 1956), in which every 10 meters the four nearest trees with circumference at breast height $(\mathrm{CBH}) \geq 15 \mathrm{~cm}$ were sampled. The edges $($ e.g. $10 \mathrm{~m})$ were not sampled to avoid the edge effect (Bianchi \& Kersten 2014, Bernardi \& Budke 2010). All sampled tree species were collected and identified by authors and specialists (cited in the acknowledgment). The taxonomic classification follows APG IV (2016) with nomenclature and authority according to Flora do

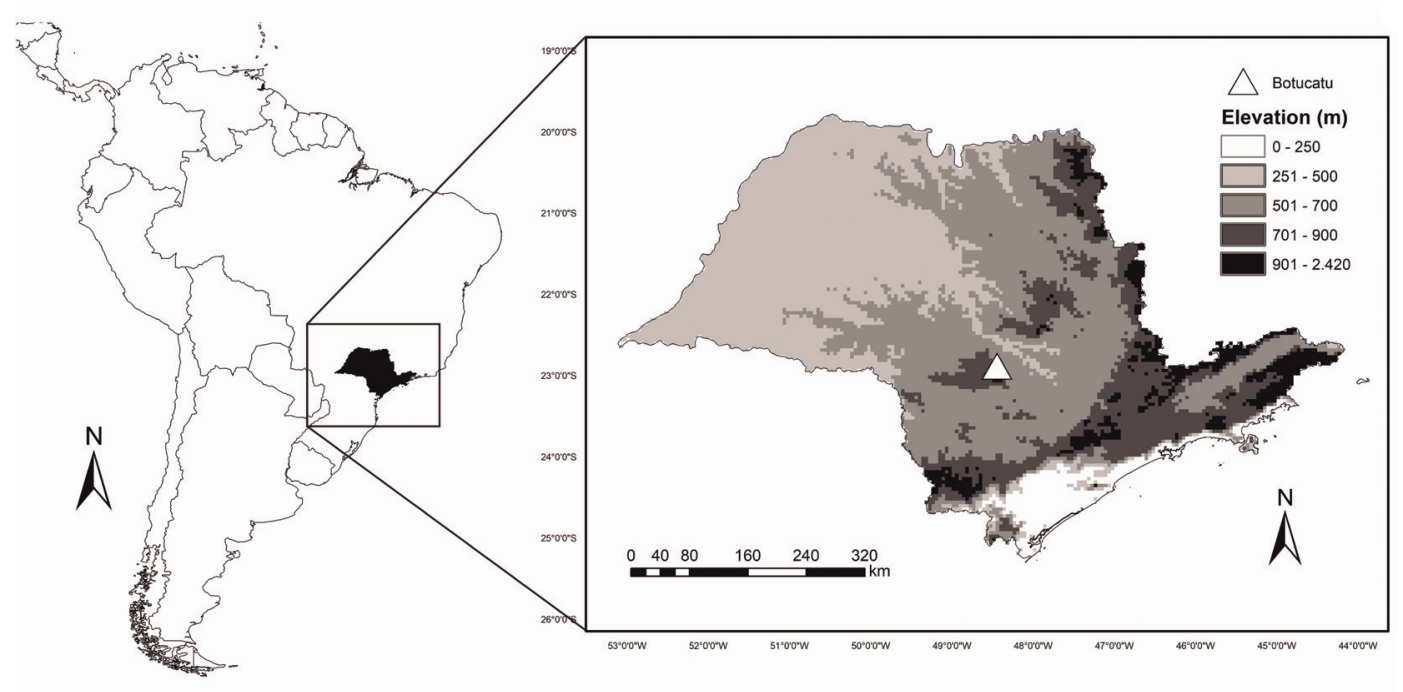

Figure 1. Location of the studied area indicated by a triangle in Botucatu municipality, São Paulo State (in black), Southeastern Brazil. 
Brasil 2020. When collected fertile, vouchers were deposited in the Herbário Rioclarense (HRCB).

For each sampled tree, we verified the presence ("phorophyte") or absence ("tree") of the vascular epiphytes. We noted the height that seedlings and adult plants were growing.

In each sampled tree, we verified the presence - In this case, a phorophyte - or absence - so, treated as tree - of the vascular epiphytes, including seedlings or adult plants, and noting the height that the epiphytes were growing (for details about epiphyte composition in the studied area, see Marcusso \& Monteiro 2016).

The phorophytes were divided, visually, in three thirds so that we could evaluate the vertical distribution of the epiphytes (following Kersten \& Waechter 2011b), checked by the occurrence in the low trunk (lowermost third), high trunk (middle third) and crown (last third).

Epiphytes were classified in holoepiphytes (never connecting to the floor) and hemiepiphytes (connection to the soil in part of the life cycle) (as per Benzing 1990). We considered the presence in all recorded strata when hemiepiphytes growing in one or more strata in the vertical distribution.

The abundance of vascular epiphytes was measured by coverage classes considering all the phorophyte (low trunk, high trunk and crown). The method we are using as proposed by Gonçalves $\&$ Waechter (2002) (see more details about these methods in Kersten \& Waechter 2011), considering five classes, as follows: one $(0-10 \%$ cover $)$, three $(11-30 \%)$, five $(31-50 \%)$, seven $(51-70 \%)$, and 10 (71-100\%).

Statistical analysis - All statistical analysis was performed using R software (R core team 2017). We used vegan (Oksanen et al. 2013) and simpleboot (Peng 2019), adopting $\alpha \leq 0.05$ and 999 randomizations for the permutation-based methods. To test differences in the type of life cycle of vascular epiphytes between vegetation types, we used a Kolmogorov-Simonov test, after testing for normality, followed by a Fisher's test. We performed a permutation-based analysis of variance (ANOVA), followed by pairwise t-tests using Bonferroni correction, to test for differences in the abundance of epiphytes among vegetation types and phorophyte variables (CBH and height).

To assess the colonization trends of phorophytes by vascular epiphytes, we performed a Correspondence Analysis (CA), by means of epiphyte individuals' abundance on the phorophytes in each vegetation type (for details and explanations of the analytical methods used, see Laube \& Zotz 2006, Wagner et al. 2015). Only tree species that serve as phorophytes in at least five individuals (68\% of the phorophytes sampled) in each vegetation types were included in this analysis (table 1). Finally, to evaluate the relationships between individuals' abundance (predict variable) and the number of phorophytes (response variable) for every tree species sampled, within each vegetation type, a linear regression by bootstrap method was carried out. We reported $\mathrm{p}$ and $\mathrm{R}^{2}$ values from the bootstrap analysis outputs and we inspected scatterplots to determine any outlier and Pearson's correlation.

\section{Results}

A total of 72 tree species were recorded in the SSF, of which 40 were phorophytes (56\%), while 41 tree species were sampled in the SF, with 29 phorophytes ( $71 \%$, table 2$)$. The most abundant tree species in both vegetation types are given in table 1 .

We found $42.2 \%$ of all sampled trees in both vegetation types holding epiphytes. More trees serve as support for epiphytes in the SF (56\% of the sampled trees) than in the SSF (28\%) (table 2). Epiphyte life cycle differed between the two vegetation types $(P<0.5)$, with both holoepiphyte and hemiepiphytes more common in the SF (table 2) than in the SSF, where only three trees hold hemiepiphytes. On the other hand, epiphyte coverage did not show differences between the two studied vegetation types $(P=0.1)$ (table 3).

Vertical distribution showed differences between vegetation types $(P<0.01)$, with more epiphytes found in the lower and higher trunks in the SF, whereas in the SSF they were mostly in the crown (figure 2). Epiphytes abundance in both vegetation types vary significantly in relation to the phorophytes height (ANOVA SSF: pseudo-F $=19.76$; $\mathrm{P}<0.005$; $\mathrm{SF}$ : pseudo-F $=7.936 ; \mathrm{P}<0.005)$ and the $\mathrm{CBH}$ (ANOVA: SSF: pseudo-F $=20.51 ; \mathrm{P}<0.005$; SF: pseudo-F $=7.671 ; \mathrm{P}<0.05)$. In general, we found a greater abundance of epiphytes (higher coverage classes) in the trees with the largest $\mathrm{CBH}$ and heights, in both vegetation types studied (figure 3 ).

The first two axes of the CA ordination (figure 4) were significant in both vegetation types $(\mathrm{P}<0.05)$. In the SSF, the first axis explained $63.1 \%$ of the total of variance and the second axis $31.1 \%$, while for the $\mathrm{SF}$, the first axis explained $87.1 \%$ and the second axis $12.9 \%$. The CA showed a segregation trend of 
Table 1. Tree species with the acronym used and phorophytes considered in the Correspondence Analysis, recorded in the Seasonal Semideciduous Forest and Swamp Forest in Botucatu municipality, São Paulo State, Brazil. (- means that the species does not occur in the vegetation type).

\begin{tabular}{|c|c|c|c|}
\hline \multirow[t]{2}{*}{ Tree species } & \multirow[t]{2}{*}{ Acronyms } & $\begin{array}{c}\text { Seasonal } \\
\text { Semideciduous } \\
\text { Forest }\end{array}$ & Swamp Forest \\
\hline & & \multicolumn{2}{|c|}{ Trees sampled / phorophytes $(\%)$} \\
\hline Protium heptaphyllum (Aubl.) Marchand & Prohep & $2 / 1(50)$ & $61 / 37(60.6)$ \\
\hline Magnolia ovata (A.St.-Hil.) Spreng. & Magova & - & $46 / 28(60.8)$ \\
\hline Tapirira guianensis Aubl. & Tapgui & - & $41 / 24(58.5)$ \\
\hline Cordiera sessilis (Vell.) Kuntze & Corses & 27/4 (14.8) & - \\
\hline Myrsine gardneriana A. DC. & Myrgar & - & 23/11 (47.8) \\
\hline Metrodorea nigra A. St.-Hil. & Metnig & $20 / 3(15)$ & $2 / 1(50)$ \\
\hline Croton floribundus Spreng. & Croflo & $17 / 8(47)$ & $2 / 1(50)$ \\
\hline Hedyosmun brasiliense Mart. & Hedbra & - & $18 / 6(33.3)$ \\
\hline Esenbeckia grandiflora Mart. & Esegra & $15 / 2(13.3)$ & $2 / 1(50)$ \\
\hline Maytenus gonoclada Mart. & Maygon & $14 / 0(0)$ & $3 / 0(0)$ \\
\hline Actinostemon concepcionis (Chodat \& Hassl.) Hochr. & Actcon & $17 / 0(0)$ & - \\
\hline Dendropanax cuneatus (DC.) Decne. \& Planch. & Dencun & - & $16 / 11(68.7)$ \\
\hline Pera glabrata (Schott) Poepp. ex Baill. & Pergla & $5 / 2(40)$ & $11 / 7(63.6)$ \\
\hline Casearia sylvestris $\mathrm{Sw}$. & Cassyl & $15 / 6(40)$ & - \\
\hline Hirtella hebeclada Moric. ex DC & Hirheb & $13 / 1(7.7)$ & $1 / 1(100)$ \\
\hline Handroanthus umbellatus (Sond.) Mattos & Hanumb & - & $13 / 11(84.6)$ \\
\hline Ocotea velutina (Nees) Mart. ex B.D.Jacks. & Ocovel & $13 / 5(38.5)$ & - \\
\hline Copaifera langsdorfii Desf. & Coplan & $12 / 5(16.7)$ & - \\
\hline Mollinedia elegans Tul. & Molele & $11 / 5(45.4)$ & - \\
\hline
\end{tabular}

Table 2. Trees, phorophytes, life cycle and mean size of the trees and phorophytes in the Seasonal Semideciduous Forest and Swamp Forest in Botucatu municipality, São Paulo State, Brazil. HEM: hemiepiphyte; HOL: holoepiphyte; CBH: circumference at breast height; $\mathrm{cm}$ : centimeters; m: meters. Different letters indicate significant differences in the mean values of life cycle between vegetation types $(\mathrm{P}<0.05)$.

\begin{tabular}{lcc}
\hline Trees, phorophytes and life cycle of the epiphytes & Seasonal Semideciduous Forest & Swamp Forest \\
\hline Trees & 316 & 316 \\
Total number of sampled trees & 29 & 27 \\
Total of trees families sampled & $227 / 71.8 \%$ & $138 / 43.7 \%$ \\
Trees sampled without epiphytes & $89 / 28.2 \%$ & $178 / 56.3 \%$ \\
Trees sampled holding epiphytes & $70 / 40$ & $41 / 29$ \\
Trees species / Phorophytes species & & \\
Phorophytes and life cycle & 89 & 178 \\
Total number of sampled phorophytes & $86 / 96 . \%^{\mathrm{a}}$ & $121 / 68 \%^{\mathrm{b}}$ \\
Phorophytes holding HOL & $0^{\mathrm{a}}$ & $17 / 9.6 \%^{\mathrm{b}}$ \\
Phorophytes holding HEM & $3 / 3.4 \%^{\mathrm{a}}$ & $40 / 2 \%^{\mathrm{b}}$ \\
Phorophyte holding HOL and HEM & & \\
Structural aspects & $49 \pm 39$ & $42.4 \pm 28.5$ \\
Mean total CBH (cm) & &
\end{tabular}


Table 2 (continuation)

\begin{tabular}{lcc}
\hline Trees, phorophytes and life cycle of the epiphytes & Seasonal Semideciduous Forest & Swamp Forest \\
\hline Mean phorophytes CBH $(\mathrm{cm})$ & $73.2 \pm 48.1$ & $51.4 \pm 32.3$ \\
Mean total height $(\mathrm{m})$ & $10 \pm 4$ & $9.7 \pm 4$ \\
Mean phorophytes height $(\mathrm{m})$ & $12.5 \pm 4.6$ & $10.7 \pm 3.7$ \\
\hline
\end{tabular}

Table 3. Abundance of vascular epiphytes assessed by coverage classes in the Seasonal Semideciduous Forest and Swamp Forest in Botucatu municipality, São Paulo State, Brazil. Percentages refer to the total number of sampled phorophytes.

\begin{tabular}{lcc}
\hline Epiphytes coverage (\%) & Seasonal Semideciduous Forest & Swamp Forest \\
\hline $0-10$ & $67 / 75.3 \%$ & $125 / 70.2 \%$ \\
$10-30$ & $16 / 18 \%$ & $24 / 13.5 \%$ \\
$30-50$ & $6 / 6.7 \%$ & $19 / 10.7 \%$ \\
$50-70$ & 0 & $8 / 4.7 \%$ \\
$70-100$ & 0 & $2 / 1.1 \%$ \\
\hline
\end{tabular}

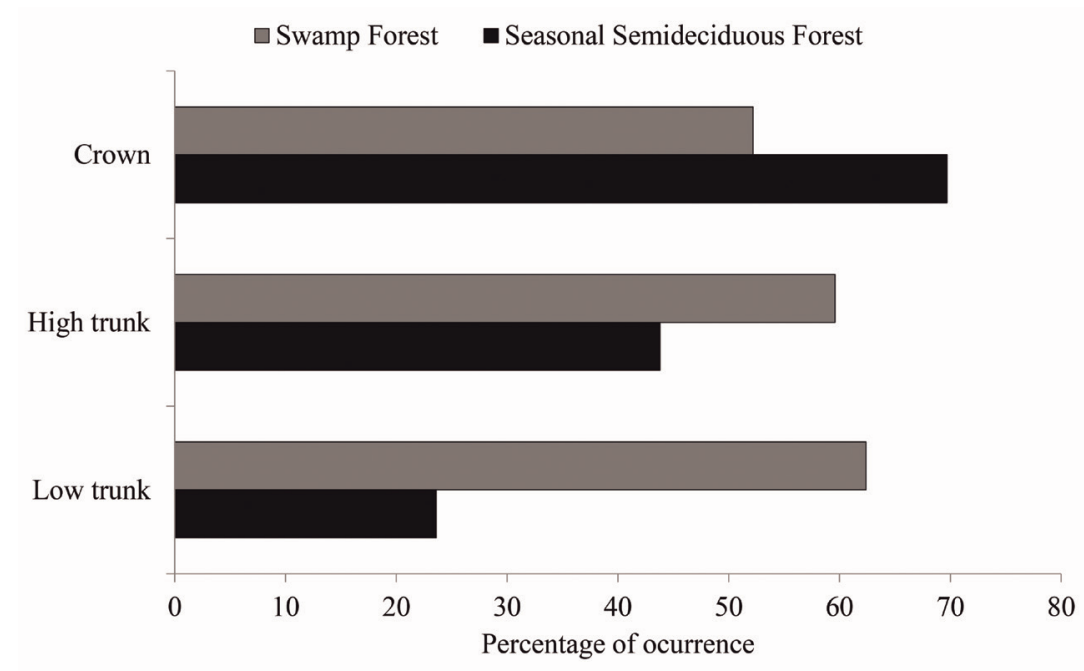

Figure 2. Vertical distribution of vascular epiphytes in two vegetation types, Seasonal Semideciduous Forest and Swamp Forest in Botucatu municipality, São Paulo State, Brazil.

phorophytes, according to their epiphytes coverage, and revealed different species associated with each coverage note (figure 4). In general, the ordination diagram showed Ocotea velutina, Mollinedia elegans and Croton floribundus related to the higher epiphyte coverage in the SSF (figure 4a), and Protium heptaphyllum, Handroanthus umbellatus, Magnolia ovata and Tapirira guianensis in the SF.

Overall, we observed a strong association (correlation values) between the abundance of tree species and phorophytes in both vegetation types (figure 5). However, both adjusted $\left(\mathrm{R}^{2}\right)$ and fitted values ( $\mathrm{p}$-values) of linear regressions differed, with the variation in the number of phorophytes with the variation in the number of individuals being stronger in the SF.

\section{Discussion}

Macroclimate strongly influence vascular epiphytes distribution at a large scale and, in the same way, microclimate is also an important variable (Gentry \& Dodson 1987, Breier 2005, Furtado \& Menini Neto 2018), even in contiguous different forest types. Small moister areas in a given vegetation type can promote the epiphytic colonization (Waechter \& Baptista 2004, Kersten et al. 2009, Bonnet et al. 2010a, Joanitti 2013, Furtado \& Menini Neto 2018), as demonstrated in the present study by the higher number of phorophytes recorded in the SF. Considering that epiphytes tend to be more limited by water availability than nutrients (Laube \& Zotz 2003, Becker et al. 2015), this riparian 


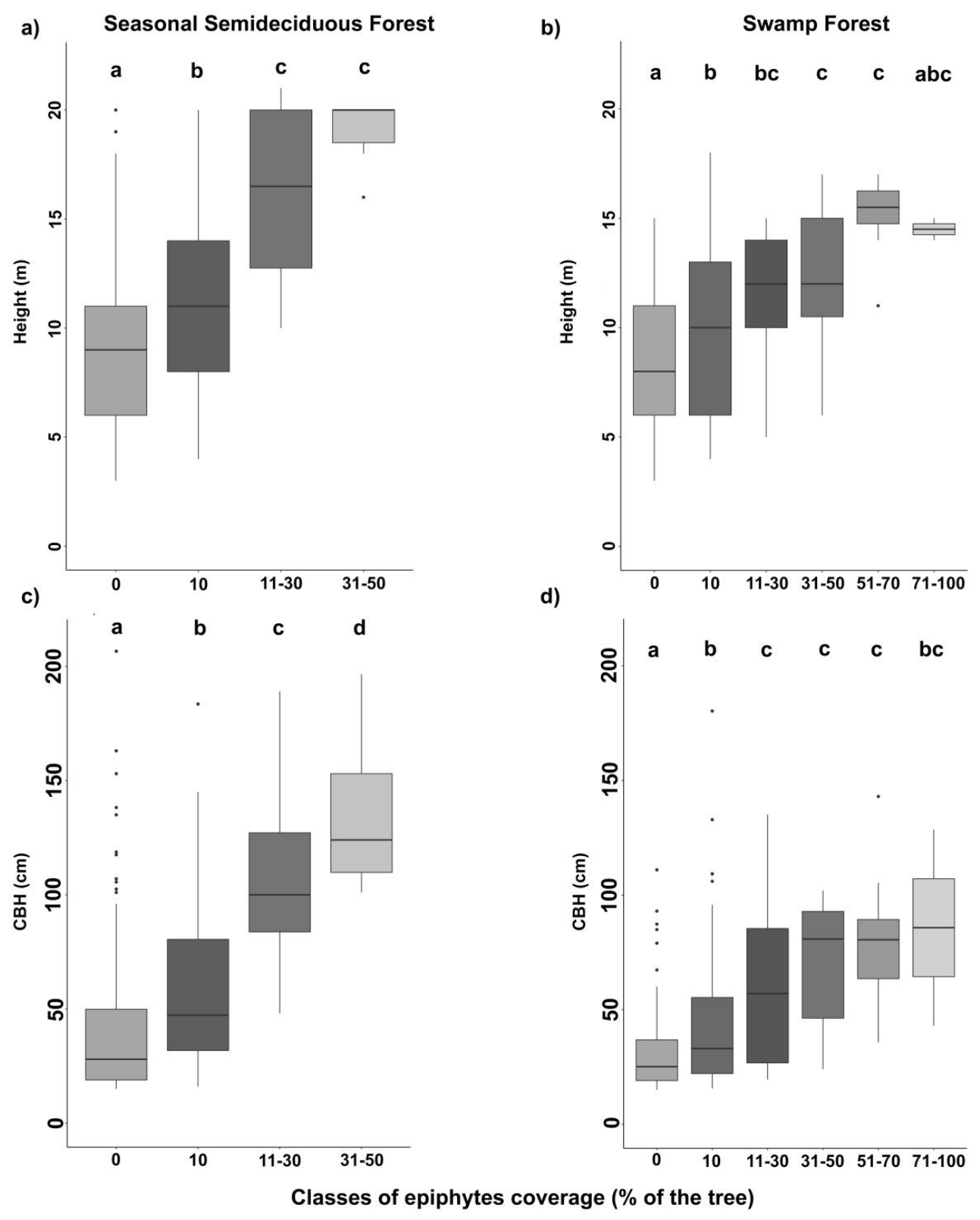

Figure 3. Mean values of height $(\mathrm{a}, \mathrm{b})$ and $\mathrm{CBH}$ (c,d - circumference at breast height) in relation to epiphytes coverage of the phorophytes in two vegetation types, Seasonal Semideciduous Forest and Swamp Forest in Botucatu municipality, São Paulo State, Brazil. Different letters indicate significant differences in the mean values of life cycle between vegetation types $(\mathrm{P}<0.05)$.

forest embed in a seasonal macroclimate region would have moister microclimatic conditions, because of water evaporation provided by waterlogged soils, affecting positively vascular epiphytes (Waechter \& Baptista 2004, Kersten et al. 2009, Bonnet et al. 2010b, Wagner et al. 2015, Padilha et al. 2017).

The differences of life cycle between the vegetation types (table 2 ) might be mainly due to the abundance of Philodendron appendiculatum Nadruz \& Mayo (Araceae) in SF, a species recorded as primary and secondary hemiepiphyte (Marcusso \& Monteiro 2016). The higher abundance of $P$. appendiculatum in SF is probably the reason of more epiphytes in the trunks in this forest, as this species is common in this stratum. This species is almost absent in SSF. The prevalence of the secondary hemiepiphytes in the lower strata caused by Araceae (Rogalski et al. 2016) supports the observed vertical distribution found here.

More epiphytes growing on the crown in the SSF suggest that the higher luminosity may offer better conditions to the shade-intolerant species; besides, its predominantly horizontal substrate may have more accumulation of organic matter, as opposed to the trunk, that is usually vertical (ter Steege \& Cornelissen 

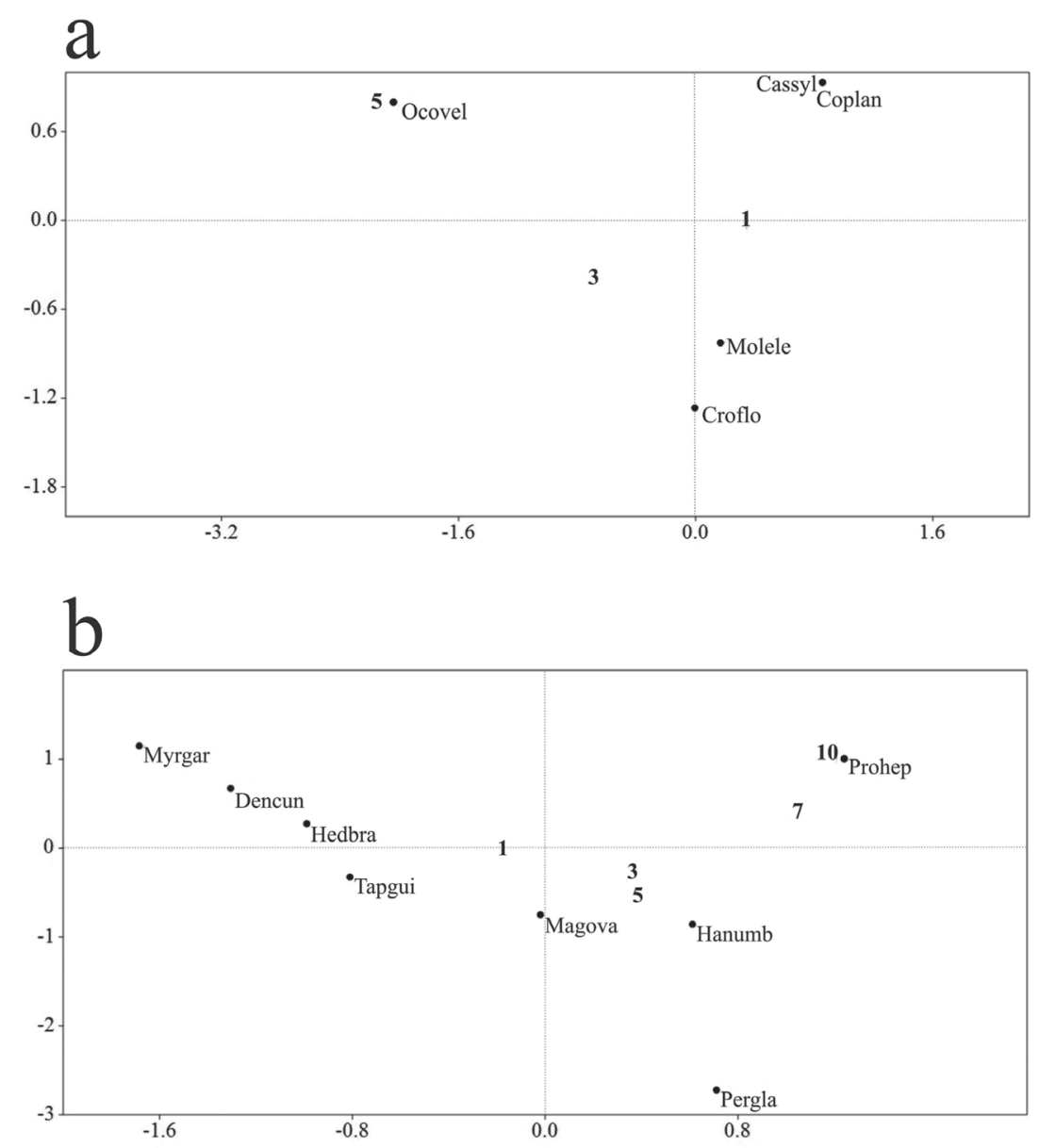

Figure 4. Correspondence analysis between phorophyte species and epiphyte coverage notes (numbers) in the Seasonal Semideciduous Forest (A) and Swamp Forest (B) Forest in Botucatu municipality, São Paulo State, Brazil (acronyms according to table 1).

1989, Nieder et al. 2001, Martínez-Melendez et al. 2008, Zhao et al. 2015). Alternatively, regarding the SF, the prevalence of epiphytes in the trunk may occur perhaps because of differential humidity and light in the vertical gradient (Benzing 1990, Bathagin et al. 2012). In the SF, as humidity is high in the understory, shade-tolerant species may be favoured in this vegetation type (e.g. Bathagin et al. 2012).

Relationships between vascular epiphytes and the phorophyte size as recorded here are supported by others studies as well (Breier 2005, Flores-Palacios \& García-Franco 2006, Bonnet et al. 2007, Orihuela \& Waechter 2009, Bonnet et al. 2010 a, Obermüller et al. 2012, Zhao et al. 2015). The size of a phorophyte tend to be associated with tree age (Yeaton \& Gladstone 1982, Zotz \& Vollrath 2003, Zhao et al. 2015), therefore older phorophytes would support more epiphytes as there will be longer time in which they are available to be colonized (Bonnet et al. 2010a, Zhao et al. 2015).
The most abundant tree species in the SF were also those with more phorophytes, in agreement with Fontoura et al. (2009), but this relationship was weak in the SSF. Some abundant tree species in the SSF have none or little epiphytes either because they have small diameter and smooth bark (e.g. Actinostemon), or perhaps there are other factors affecting epiphyte distribution (e.g. Maytenus) offering few suitable substrates to the colonization by epiphytes (Trapnell \& Hamrick 2006, Zhao et al. 2015). Factors as bark type (Sanford 1974, Wyse \& Burns 2011), inhibitory substances, mycorrhiza presence (Trapnell \& Hamrick 2006, Martínez-Melendez et al. 2008, Sathiyadash et al. 2012, Einzmann et al. 2015), lack of bryophytes cover (Zotz \& Vollrath 2003), low water-holding capacity (Callaway et al. 2002), host tree phenology (Einzmann et al. 2015) or chance (Fontoura et al. 1995, Zotz \& Vollrath 2003) are known to influence colonization by epiphytes.

In SF, some phorophyte species have higher epiphytes cover. Most abundant tree species were also 

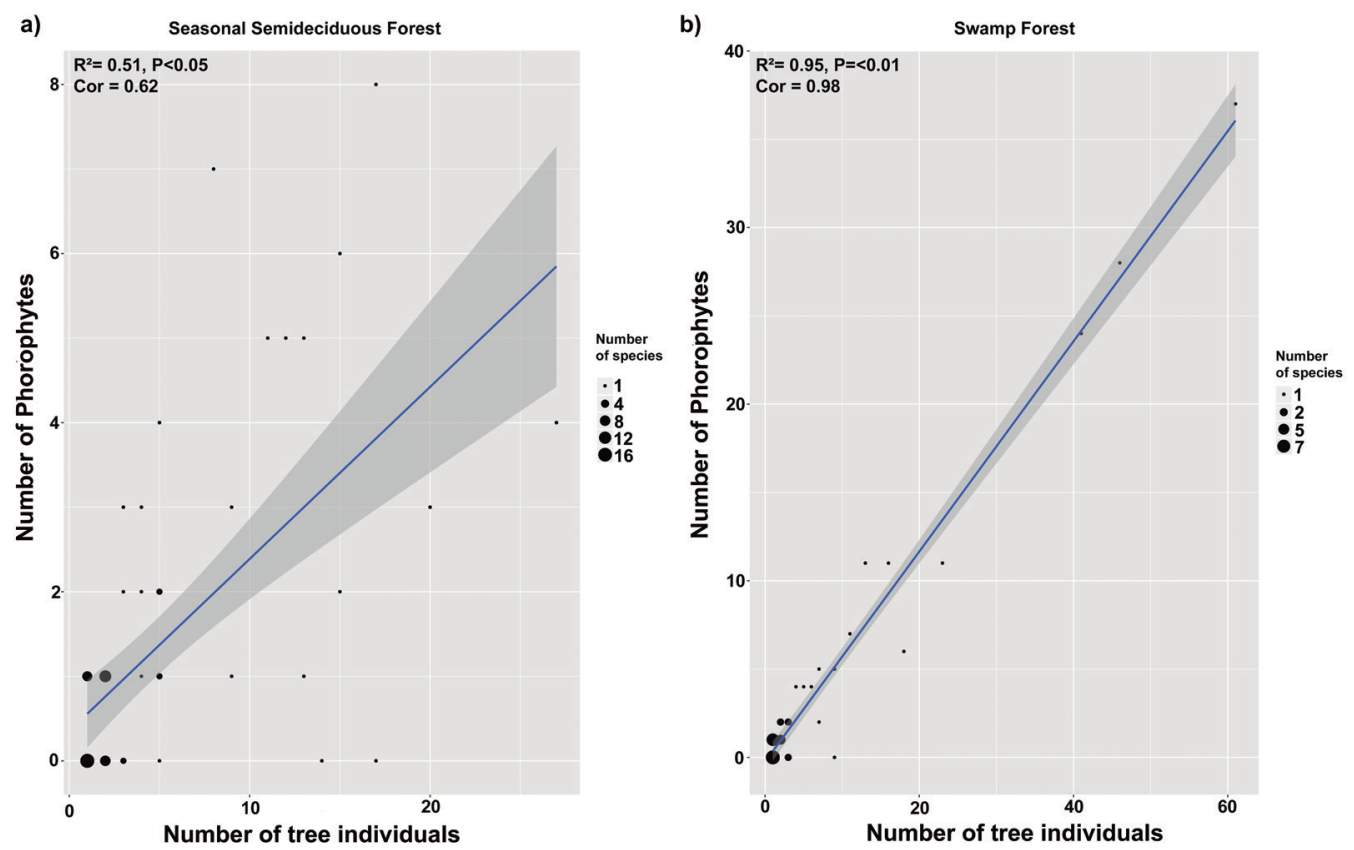

Figure 5. Linear regression between the number of tree individuals and phorophytes density in the Seasonal Semideciduous Forest (a) and in the Swamp Forest (b) in Botucatu municipality, São Paulo State, Brazil. •: tree species; grey area - Confidence interval for the regression line.

the best phorophytes, like P. heptaphyllum and $M$. ovata. The abundance of phorophyte species and the lack of restrictive humidity conditions do not act as barriers to colonization on suitable substrates in SF, as it may occur in the SSF. The lower tree species richness in SF (due to hypoxia caused by the waterlogged soils, Ivanauskas et al. 1997) is an important factor when phorophyte specificity is analyzed (Callaway et al. 2002, Wagner et al. 2015). In the forest with more species of phorophytes, regarding the colonization by epiphyte, specificity tend to be lower than in poor tree species forest, as in the SF (Laube \& Zotz 2006, Fontoura et al. 2009, Wagner et al. 2015). According to Ceballos et al. (2016), the interactions between vascular epiphytes and phorophytes are mainly related to the species density, additionally to the tree size and tree bark texture. These may help to justify the low phorophyte specificity in the SSF (Fontoura 1995, Fontoura et al. 2009, Silva et al. 2010, Benavides et al. 2011, Joanitti 2013).

Summarizing, vascular epiphytes distribution showed differences between the vegetation types studied. The hemiepiphytes are practically absent in the SSF, while the reverse happens in the SF, with both hemi and holoepiphytes growing more in the trunk, where its moister conditions allow the growth of shade-tolerant types in the understory of the SF. Nonetheless, in the SSF, epiphytes occurred more in the canopy, mainly represented by xerophytic and heliophytic species, likely because of the dry conditions acting as a barrier to the colonization of more shade-tolerant species in the lower strata. In the SSF, the epiphyte colonization is positively correlated with phorophytes size, and it is likely that humidity might limit the colonization in small trees. Besides, low phorophytes specificity may occur. In the SF, where the humidity is not a limiting factor, tree density may be more important to drive epiphyte colonization than the phorophytes size, as the most abundant tree species had more phorophytes and higher epiphyte cover.

These results could help the management of restored forests, where biological enrichment might be necessary to increase the diversity of the vascular epiphytes (e.g. Duarte \& Gandolfi 2017). In addition, old and high trees show their role as holding high biomass and allowing maintenance of a higher local pool of epiphyte species. Forests where selective logging is allowed, management might be necessary to decrease the impact on the vascular epiphytes, maintaining these strategic phorophytes (Wolf 2005).

\section{Acknowledgments}

We thank the Conselho Nacional de Desenvolvimento Científico e Tecnológico (process 
133495/2013-2) for the MSc scholarship to the first author; Eliana Gabriel for the permission to access and study in the Escola do Meio Ambiente vegetation; Pablo Sanine for help in the field work; Gabriel Pavan Sabino, Leonardo Biral, Rodrigo Ferreira de Morais, Pedro Luís Rodrigues de Moraes, Bruno Sampaio Amorim and Ernesto Pedro Dickfeldt for helping with tree identification; Henrique Lauand Ribeiro for the map design; and Cláudia Baider and two anonymous referee for the valuable contribution in the manuscript version.

\section{Literature cited}

Alves, R.J.B., Kolbek, J. \& Becker, J. 2008. Vascular epiphyte vegetation in rocky savannas of southeastern Brazil. Nordic Journal of Botany 26: 101-117.

APG. 2016. An update of the Angiosperm Phylogeny Group classification for the orders and families of flowering plants: APG IV. Botanical Journal of the Linnean Society 181: 1-20.

Arévalo, R. \& Betancur, J. 2004. Diversidad de epífitas vasculares em cuatro bosques del sector suroriental de La serranía de Chiribiquete, Guayana Colombiana. Caldasia 26: 359-380.

Arévalo, R. \& Betancur, J. 2006. Vertical distribution of vascular epiphytes in four forest types of the Serranía de Chiribiquete, Colombian Guayana. Selbyana 27: 175-185.

Barthlott, W., Schmit-Neuerburg, V., Nieder, J. \& Engwald, S. 2001. Diversity and abundance of vascular epiphytes: a comparison of secondary vegetation and primary montane rain forest in the Venezuelan Andes. Plant Ecology 152: 145-156.

Basílio, G.A., Barbosa, D.E.F., Furtado, S.G., Silva, F.R. \& Menini Neto, L. 2015. Community ecology of epiphytic Bromeliaceae in a remnant of Atlantic Forest in Zona da Mata, Minas Gerais State, Brazil. Hoehnea 42: 21-31.

Bataghin, F.A., Barros, F. \& Pires, J.S.R. 2012. Riqueza e estratificação vertical de epífitas vasculares na Estação Ecológica de Jataí - área de Cerrado no Sudeste do Brasil. Hoehnea 39: 615-626.

Becker, D.F.P., Müller, A. \& Schmitt, J.L. 2015. Influência dos forófitos Dicksonia sellowiana e Araucaria angustifolia sobre a comunidade de epífitos vasculares em floresta com araucária. Floresta 45: 781-790.

Benavides, A.M., Vasco, A., Duque, A.J. \& Duivenvoorden, J.F. 2011. Association of vascular epiphytes with landscape units and phorophytes in humid lowland forests of Colombian Amazonia. Journal of Tropical Ecology 27: 223-237.

Benzing, D.H. 1990. Vascular epiphytes. General biology and related biota. Cambridge University Press, Cambridge.
Benzing, D. H. 1995. The physical mosaic and plant variety in forest canopies. Selbyana 16: 159-168.

Bernardi, S \& Budke, J.C. 2010. Estrutura da sinúsia epifítica e efeito de borda em uma área de transição entre floresta estacional semidecídua e floresta ombrófila mista. Floresta 40: 81-92.

Bianchi, J.S. \& Kersten, R.A. 2014. Edge effect on vascular epiphytes in a subtropical Atlantic Forest. Acta Botanica Brasilica 28: 120-126.

Bonnet, A. \& Queiroz, M.H. 2006. Estratificação vertical de bromélias epifítias em diferentes estádios sucessionais da Floresta Ombrófila densa, Ilha de Santa Catarina, Santa Catarina, Brasil. Revista Brasileira de Botânica 29: 217-228.

Bonnet, A., Queiroz, M.H. \& Lavoranti, O.J. 2007. Relações de bromélias epifíticas com características dos forófitos em diferentes estádios sucessionais da floresta ombrófila densa, Santa Catarina, Brasil. Floresta 37: 83-94.

Bonnet, A., Curcio, G.R., Lavoranti, O.J., Bardall, M.L., Roderjan, C.V. 2010a. Relações de bromeliáceas epifíticas com fatores ambientais em planícies de inundação do rio Iguaçu, Paraná, Brasil. Floresta 40: 193-208.

Bonnet, A., Curcio, G.R., Lavoranti, O.J. \& Galvão, F. 2010b. Relações de epífitos vasculares com fatores ambientais nas florestas do Rio Tibagi, Paraná, Brasil. Biotemas 23: 37-47.

Breier, T.B. 2005. O epifitismo vascular em florestas do sudeste do Brasil. Tese de Doutorado, Universidade Estadual de Campinas, Campinas.

Callaway, R.M., Reinhart, K.O., Moore, G.W., Moore, D.J. \& Pennings, S.C. 2002. Epiphyte host preferences and host traits: mechanisms for species-specific interactions. Oecologia 132: 221-230.

Campos, C., Silva, M., Piroli, E. L., Cardoso, L.G. \& Barros, Z.X. 2004. Evolução do uso da terra entre 1996 e 1999 no município de Botucatu-SP. Engenharia Agrícola 24: 211-218.

Ceballos, S.J., Chacoff, N.P., Malizia, A. 2016. Interaction network of vascular epiphytes and trees in a subtropical forest. Acta Oecologica 77: 152-159.

CEPAGRI. 2018. Clima dos municípios paulistas. Available in http:/www.cpa.unicamp.br/outras-informacoes/ clima_muni_086.html (access in 17-III-2018).

Cottam, G. \& Curtis, J.T. 1956. The use of distance measures in phytosociological sampling. Ecology 37: 451-460.

Duarte, M.M. \& Gandolfi, S. 2017. Diversifying growth forms in tropical forest restoration: Enrichment with vascular epiphytes. Forest Ecology and Management 401: 89-98.

Einzmann, H.J.R., Beyschlag, J., Hofhansl, F., Wanek, W. \& Zotz, G. 2015. Host tree phenology affects vascular epiphytes at the physiological, demographic and community level. AoB PLANTS 7: plu073. 
Flora do Brasil 2020 (em construção). 2018. Jardim Botânico do Rio de Janeiro. Available in http:// floradobrasil.jbrj.gov.br/ (access in 10-I-2018).

Flores-Palacios, A. \& García-Franco, J.G. 2006. The relationship between tree size and epiphyte species richness: testing four different hypotheses. Journal of Biogeography 33: 323-330.

Fontoura, T. 1995. Distribution patterns of five Bromeliaceae genera in Atlantic Rainforest, Rio de Janeiro state, Brazil. Selbyana 16: 79-93.

Fontoura, T., Rocca, M.A., Schilling, A.C. \& Reinert, F. 2009. Epífitas da floresta seca da Reserva Ecológica Estadual de Jacarepiá, sudeste do Brasil: Relações com a comunidade arbórea. Rodriguésia 60: 71-185.

Furtado, S.G. \& Menini Neto, L. 2018. Elevational and phytophysiognomic gradients influence the epiphytic community in a cloud forest of the Atlantic phytogeographic domain. Plant Ecology 219: 677-690.

Gentry, A.H. \& Dodson, C.H. 1987. Diversity and biogeography of neotropical vascular epiphytes. Annals of the Missouri Botanical Garden 74: 205-233.

Gonçalves, C.N. \& Waechter, J.L. 2002. Epífitos vasculares sobre espécimes de Ficus organensis isolados no norte da planície costeira do Rio Grande do Sul: padrões de abundância e distribuição. Acta Botânica Brasílica 16: 429-441.

Hernandez, J.C.C., Wolf, J.H.D., Garcia-Franco, J.G. \& Gonzalez-Espinosa, M. 1999. The influence of humidity, nutrients and light on the establishment of the epiphytic bromeliad Tillandsia guatemalensis in the highlands of Chiapas, Mexico. Revista de Biologia Tropical 47: 763-773.

IBGE - Instituto Brasileiro de Geografia e Estatística. 2012. Manual técnico da vegetação brasileira. Instituto Brasileiro de Geografia e Estatística, Rio de Janeiro.

Ivanauskas, N.M., Rodrigues, R.R. \& Nave, A.G. 1997. Aspectos ecológicos de uma mata de brejo em Itatinga SP: florística, fitossociologia e seletividade de espécies. Revista brasileira de botânica 20: 139-153.

Joanitti, S.A. 2013. Epifitismo vascular em três formações vegetais distintas: mata de brejo, floresta estacional semidecidual e cerradão, pertencentes ao município de Bauru, estado de São Paulo. Dissertação de Mestrado. Universidade Estadual Paulista "Júlio de Mesquita Filho", Botucatu.

Kersten, R.A. 2010. Epífitas vasculares - Histórico, participação taxonômica e aspectos relevantes, com ênfase na Mata Atlântica. Hoehnea 37: 9-38.

Kersten, R.A., Kunyioshi, Y.S. \& Roderjan, C.V. 2009. Epífitas vasculares em duas formações ribeirinhas adjacentes na bacia do rio Iguaçu - Terceiro Planalto Paranaense. Iheringia 64: 33-43.
Kersten, R.A. \& Waechter, J.L. 2011a. Florística e estrutura de epífitas vasculares na transição entre as Florestas Ombrófilas Densa e Mista da vertente oeste da Serra do Mar paranaense, Brasil. In: J.M. Felfili, P.V. Eisenlohr, M.M.R.F. Melo, L.A. Andrade, \& J.A.A. Meira Neto (orgs.). Fitossociologia no Brasil: métodos e estudos de casos. Editora UFV, Viçosa, pp. 479-503.

Kersten, R.A. \& Waechter, J.L. 2011b. Métodos quantitativos no estudo de comunidades epifíticas In: J.M. Felfili, P.V. Eisenlohr, M.M.R.F. Melo, L.A. Andrade, \& J.A.A. Meira Neto (orgs). Fitossociologia no Brasil - métodos e estudos de casos. Editora UFV, Viçosa, pp. 231-254.

Laube, S. \& Zotz, G. 2003. Which abiotic factors limit vegetative growth in a vascular epiphyte? Funtional Ecology 17: 598-604.

Laube, S. \& Zotz, G. 2006. Neither Host-specific nor Random: Vascular Epiphytes on Three Tree Species in a Panamanian Lowland Forest. Annals of Botany 97: 1103-1114.

Leitman, P., Amorim, A.M., Sansevero, J.B.B. \& Forzza, R.C. 2015. Floristic patterns of epiphytes in the Brazilian Atlantic Forest, a biodiversity hotspot. Botanical Journal of the Linnean Society.

Madison, M. 1977. Vascular epiphytes: their systematic occurrence and salient features. Selbyana 2: 1-13.

Marcusso, G.M., Dickfeldt, E.P., Bertoni, J.E.A. \& Monteiro, R. 2016. Epífitas vasculares do Parque Estadual de Porto Ferreira, São Paulo, Brasil. Revista do Instituto Florestal 28: 119-133.

Marcusso, G.M. \& Monteiro, R. 2016. Composição florística das epífitas vasculares em duas fisionomias vegetais no município de Botucatu, estado de São Paulo, Brasil. Rodriguésia 67: 553-569.

Martínez-Meléndez, L., Pérez-Farrera, M.A. \& FloresPalacios, A. 2008. Estratificación vertical y preferencia de hospedero de las epífitas vasculares de un bosque nublado de Chiapas, México. Revista de Biologia Tropical 56: 2069-2086.

Nieder, J., Engwald, S. \& Barthlott, W. 1999. Patterns of Neotropical epiphytes diversity. Selbyana 20: 66-75.

Nieder, J., Prosperí, J. \& Michaloud, G. 2001. Epiphytes and their contribution to canopy diversity. Plant Ecology 153: 51-63.

Obermüller, A.F., Silveira, M., Salimon, C.I., Daly, D.C. 2012. Epiphytic (including hemiepiphytes) diversity en three timber species in the southwestern Amazon, Brazil. Biodiversity and Conservation 21: 565-575.

Oksanen, J., Blanchet, F.G., Friendly, M., Kindt, R., Legendre, P., Mcglinn, D., Minchin, P. R., O'hara, R. B., Simpson, G.L., Solymos, P., Stevens, M.H.H., Szoecs, E. \& Wagner, H. 2016. Vegan: Community Ecology Package. R package version 2.4-0. 
Orihuela, R.L.L. \& Waechter, J.L. 2010. Host size and abundance of hemiepiphytes in a subtropical stand of Brazilian Atlantic Forest. Journal of Tropical Ecology 26: 119-122.

Ponçano, W.L., Carneiro, C.D.R, Almeida, M.A., Pires Neto, A.G. \& Almeida, F.F.M. 1981. Mapa geomorfológico do estado de São Paulo. Instituto de Pesquisas Tecnológicas do Estado de São Paulo, São Paulo.

Padilha, P.T., Elias, G.A., Santos, R.S., Martins, R., Citadini-Zanette, V. 2017. Vascular epiphytes respond to successional stages and microhabitat variations in a subtropical forest in southern Brazil. Brazilian Journal of Botany.

Peng, R. D. 2019. Simpleboot: Simple Bootstrap Routines. R package version 1.1-7.

Putz, F.E. \& Holdbrook, M. 1986. Notes on the natural history of hemiepiphytes. Selbyana 9: 61-69.

Quaresma, A.C., Piedade, M.T.F., Feitosa, Y.O., Wittmann, F. \& ter Steege, H. 2017. Composition, diversity and structure of vascular epiphytes in two contrasting Central Amazonian floodplain ecosystems. Acta Botanica Brasilica 31: 686-697.

R Development Core Team. 2017. R: a language and environment for statistical computing. Vienna: $\mathrm{R}$ Foundation for Statistical Computing.

Rodrigues, R.R. 2000. Florestas ciliares? In: R.R. Rodrigues \& H.F. Leitão Filho (orgs.) Matas ciliares: conservação e recuperação. Editora da Universidade de São Paulo, São Paulo. pp. 91-99.

Rogalski, J.M., Reis, A., Reis, M.S. \& Queiroz, M.H. 2016. Spatial distribution of Araceae on phorophytes in different areas of submontane rainforest, Santa Catarina Island (SC), Southern Brazil. Brazilian Journal of Botany 39: 1077-1086.

Sanford, W.W. 1974. The use of epiphytic orchids to characterize vegetation in Nigeria. Botanical Journal of the Linnaean Society 68: 291-301.

Sathiyadasha, K., Muthukumara, T., Umaa, E. \& Pandey, R.R. 2012. Mycorrhizal association and morphology in orchids. Journal of Plant Interactions 7: 238-247.

Silva, I.A., Ferreira, A.W.C., Lima, M.I.S. \& Soares, J.J. 2010. Networks of epiphytic orchids and host trees in Brazilian gallery forests. Journal of Tropical Ecology 26: $1-11$.

ter Steege, H. \& Cornelissen, J.H.C. 1989. Distribution and ecology of vascular epiphytes in lownland rain forest of Guyana. Biotropica 21:331-339.
Trapnell, D.W. \& Hamrick J.L. 2006. Variety of phorophyte species colonized by the neotropical epiphyte, Laelia rubescens (Orchidaceae). Selbyana 27: 60-64.

Waechter, J.L. \& Baptista, L.R.M. 2004. Abundância e distribuição de orquídeas epifíticas em uma floresta turfosa do Brasil Meridional. In: F. Barros, G.B. Kerbauy (orgs.). Orquideologia sul-americana: uma compilação científica. Secretaria do Meio Ambiente, Instituto de Botânica, São Paulo.

Wagner, K., Mendieta-Leiva, G. \& Zotz, G. 2015. Host specificity in vascular epiphytes: a review of methodology, empirical evidence and potential mechanisms. AoB Plants 7: plu092.

Willians-Linera, G. \& Lawton, R.O. 1995. The ecology of hemiepiphytes in forest canopies. In: M.D. Lowman \& N.M. Nadkarni (orgs.). Forest Canopies.Academic Press, San Diego.

Wyse, S.V. \& Burns, V.R. 2011. Do host bark traits influence trunk epiphyte communities? New Zealand Journal of Ecology 35: 296-301.

Wolf, J.H.D. 1994. Factors Controlling the Distribution of Vascular and Nonvascular Epiphytes in the Northern Andes. Vegetatio 112: 15-28.

Wolf, J.H.D. 2005. The response of epiphytes to anthropogenic disturbance of pine-oak forests in the highlands of Chiapas, Mexico. Forest Ecology and Management 212: 376-393.

Yeaton, R.I. \& Gladstone, D.E. 1982. The pattern of colonization of epiphytes on Calabash Trees (Crescentia alata HBK.) in Guanacaste Province, Costa Rica. Biotropica 14: 137-140.

Zhao, M., Geekiyanage, N., Xu1, J., Khin, M.M., Nurdiana, D.R., Paudel, E. \& Harrison, R.D. 2015. Structure of the Epiphyte Community in a Tropical Montane Forest in SW China. PLOS ONE 10: e0122210.

Zotz, G. 2013. The systematic distribution of vascular epiphytes - a critical update. Botanical Journal of the Linnean Society 171: 453-481.

Zotz, G. 2013. "Hemiepiphyte": a confusing term and its history. Annals of botany 111: 1015-20.

Zotz, G. 2016. Plants on Plants - The Biology of Vascular Epiphytes. Heidelberg, Berlin.

Zotz, G. \& Vollrath, B. 2003. The epiphyte vegetation of the palm Socratea exorrhiza: correlations with tree size, tree age and bryophyte cover. Journal of Tropical Ecology 19: 81-90. 